MINERALOGIA, 41, No 1-2: 35-53 (2010)

DOI: $10.2478 / v 10002-010-0004-1$

www.Mineralogia.pl

MineRALOGICAL Society of Poland

Polskie TOWARZYSTWO MINERALOgICZNE

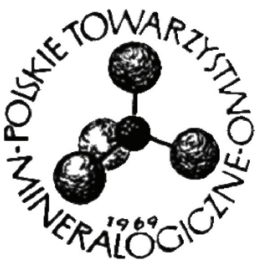

Original paper

\title{
Polymetallic mineralization in Triassic strata of the NW part of the Kraków-Częstochowa Monocline
}

\author{
Jadwiga PIECZONKA ${ }^{1}$ \\ ${ }^{1}$ AGH - University of Science and Technology, Faculty of Geology, Geophysics and Environment Protection; \\ al. Mickiewicza 30, 30-059 Kraków, Poland \\ email: jpieczon@geolog.geol.agh.edu.pl
}

Received: March 1, 2009

Received in revised form: October 13, 2010

Accepted: December 14, 2010

Available online: February 5, 2011

\begin{abstract}
A new association of ore minerals has been found in the Lower and Middle Triassic rocks in the vicinity of the village of Woźniki in the NW part of the Upper Silesian district. In addition to the typical $\mathrm{Zn}-\mathrm{Pb}-\mathrm{Fe}$ association in dolomites, copper sulphides have been detected in the sandstones and conglomerates of the Lower Bunter. Copper mineralization occurs in the sandstone matrix and is represented by bornite, chalcopyrite, chalcocite, tetrahedrite and covellite. High admixtures of zinc in $\mathrm{Cu}$ sulphides and admixtures of copper in $\mathrm{Zn}-\mathrm{Pb}$ sulphides suggest a common source for the metal-transporting fluids and a single period of sulphide crystallization.
\end{abstract}

Key-words: copper mineralization, Bunter, Upper Silesian ore district

\section{Introduction}

Initial geological work in the NW part of the Kraków-Częstochowa monocline in the early 1950s was carried out by the Geological Enterprises from Kraków and Kielce and the Polish Geological Institute (PGI) from Warsaw. During this work, the Bibiela-Kalety and the Miotek-Zielona $\mathrm{Zn}-\mathrm{Pb}$ deposit areas were discovered and a follow-up campaign was carried out by the PGI (Wielgomas 1959, 1961, 1975, 1979, 1980; Kasprzak 1969; Kerber 1977; Kasprzak, Kerber 1979). In the 1980s, the Academy of Mining and Metallurgy in 
Kraków and the PGI continued the work within a state-financed project. Its goal was twofold, i.e. to prepare a report on the previously discovered small deposits of $\mathrm{Zn}-\mathrm{Pb}$ and to assess the potential of the NW part of the Upper Silesian ore district which at that time had been poorly recognized (Strzelska-Smakowska 1993). The area between Brusek and Koszęcin to the west of the known deposits and Koziegłowy immediately to the north was the focus of a drilling program (Fig. 1,2).

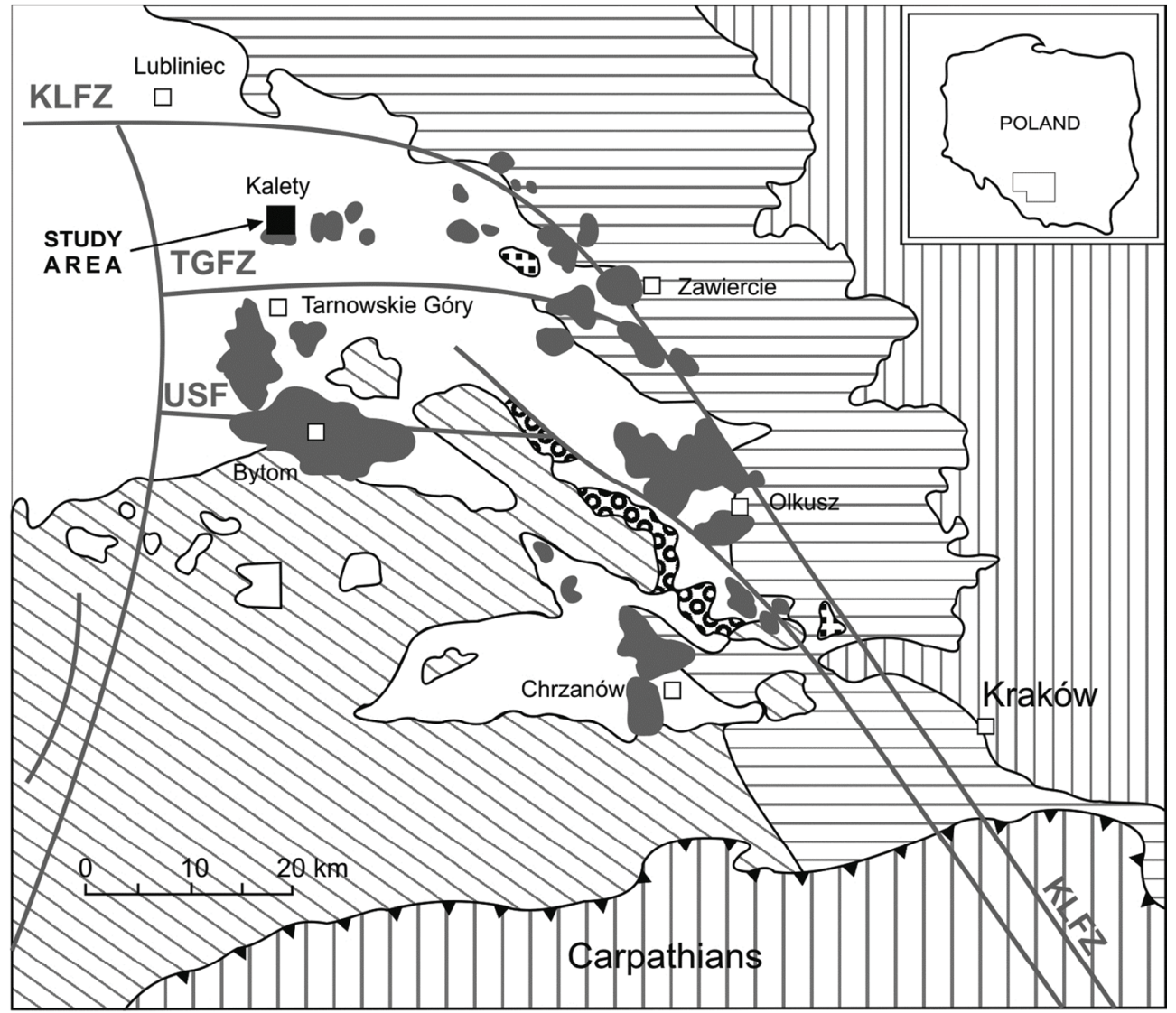

11 2 $3 \longdiv { 0 } 4$ 756
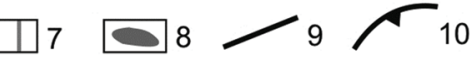

Fig. 1. Position of the Upper Silesian Zn-Pb strata-bound ores in relation to the major Palaeozoic fracture zones and faults (after Sass-Gutkiewicz, Dżułyński 1998. Palaeozoic tectonics simplified after Herbich 1981 and Morawska 1997, vide Sass-Gustkiewicz 2001).

1 - Cretaceous, 2 - Jurassic, 3 - Triassic, 4 - Permian, 5 - Carboniferous, 6 - Devonian, 7 -Cretaceous-Tertiary of the Carpathians, $8-\mathrm{Zn}-\mathrm{Pb}$ ore deposits, 9 - fracture zones and major faults, 10 - Carpathian nappes. The Cainozoic cover is not shown. KLFZ - the Kraków-Lubliniec Fracture Zone, TGFZ - the Tarnowskie Góry Fault Zone, USF - the Upper Silesian Fault. 


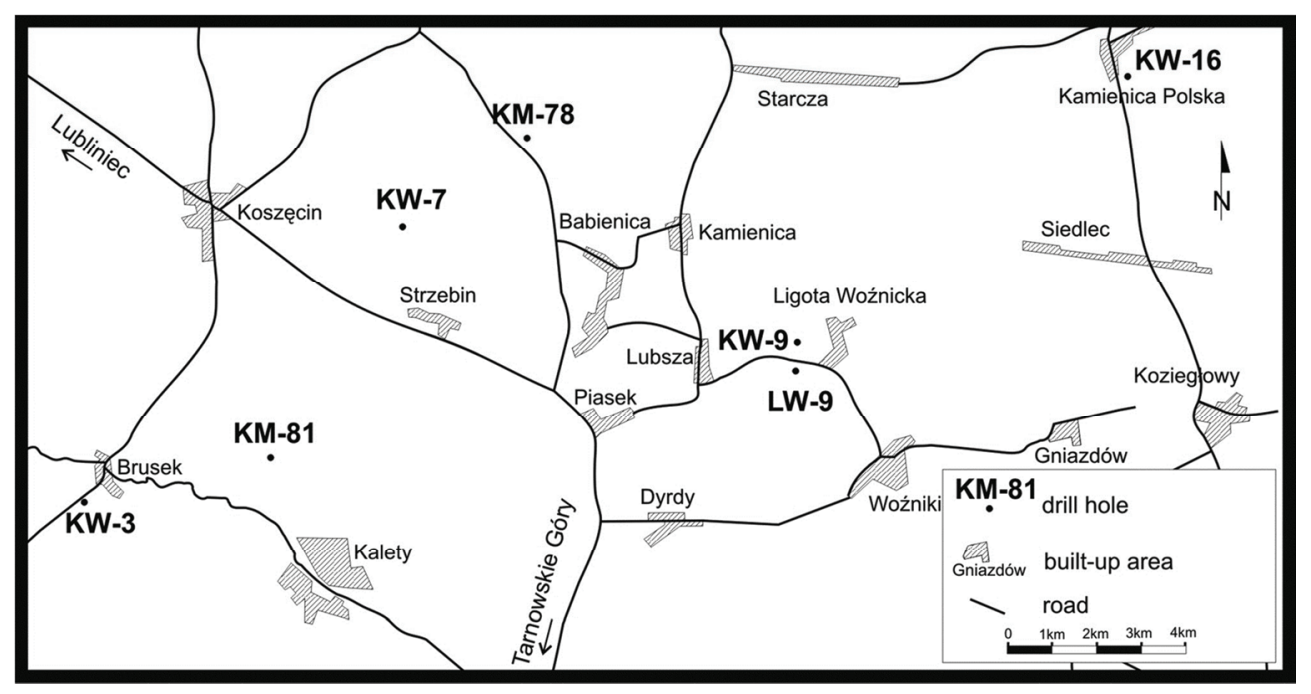

Fig. 2. Location of drill holes

The present work focussed not only on the Muschelkalk strata but also on the Bunter sediments beneath. Examination of drill cores led to the discovery of a new type of ore mineralization composed of chalcopyrite, bornite, tetrahedrite, chalcocite and covellite, associated with the widespread $\mathrm{Zn}-\mathrm{Pb}-\mathrm{Fe}$ sulphides typical of the Triassic strata. The association of copper sulphides is described in detail here, although the presence of chalcopyrite was previously noted in some places of the Upper Silesian ore district by Harańczyk (1962) and Przeniosło (1974). Harańczyk (1962) also described two sulphosalts co-occurring with botryoidal sphalerite, namely Tl-jordanite $\left[(\mathrm{Pb}, \mathrm{Tl})_{14} \mathrm{As}_{6} \mathrm{~S}_{23}\right]$ and gratonite $\left(\mathrm{Pb}_{27} \mathrm{As}_{12} \mathrm{~S}_{15}\right)$.

\section{Methods}

Samples for mineralogical studies were collected from the cores of the following drill holes: KW-3, KW-7, KW-9, KW-16, KM-78, KM-81 and LW-9 (Fig. 2). The cores provide data to describe the geology and stratigraphy of the area. Special attention was paid to 20 samples from the Lower Bunter. A Nikon-Optiphot reflected light microscope was used in the mineralogical study. Microprobe analyses were carried out at the Institute of Nonferrous Metals in Gliwice using a JEOL Superprobe 753 and later at AGH-UST in Kraków using an ARL SEMQ instrument, applying the following conditions, spectral lines and standards: voltage $20 \mathrm{kV}$; probe current $120 \mathrm{~mA}$; sample current $9 \mathrm{nA}$; counting time $20 \mathrm{~s}$; $\mathrm{SK} \alpha$ and $\mathrm{FeK} \alpha\left(\mathrm{FeS}_{2}\right), \mathrm{CuK} \alpha(100 \%), \mathrm{PbM} \alpha(\mathrm{PbS}), \mathrm{ZnK} \alpha(100 \%), \mathrm{AsL} \alpha(100 \%), \mathrm{SbL} \alpha$ (100\%), AgL $\alpha$ (100\%). Detection limits were $\mathrm{S} \leq 0.05 \%, \mathrm{Fe} \leq 0.02 \%, \mathrm{Cu} \leq 0.02 \%$, $\mathrm{Pb} \leq 0.05 \%, \mathrm{Zn} \leq 0.02 \%$, As $\leq 0.02 \%, \mathrm{Sb} \leq 0.02 \%$ and $\mathrm{Ag} \leq 0.02 \%$. Analyses of thiosulphates were carried out using an EDS system combined with an electron scanning microscope FEI Quanta-200 FEG (20 kV acceleration voltage) at the Department of 
Mineralogy, Petrography and Geochemistry in the Faculty of Geology, Geophysics and Environmental Protection (AGH-UST).

\section{Lithostratigraphic profile}

The geology of the Upper Silesian area is relatively well known (Bukowy 1964, Ekiert 1971, Gruszczyk 1956, Smolarska 1968, Górecka 1993) and its stratigraphy has been described and discussed by Siedlecki (1952), Senkowiczowa and Szyperko-Śliwczyńska (1961), Śliwiński (1961) and Wyczółkowski (1978).

All Triassic members are present in the study area. They lie unconformably mostly on Carboniferous shales, sandstones and carbonate rocks but, in some places, the underlying rocks are Silurian schists, Permian conglomerates and Devonian carbonate rocks (Fig. 3). Drill core examination underpins the descriptions of the Triassic lithologies in this paper.

\begin{tabular}{|c|c|c|c|c|c|}
\hline \multirow{6}{*}{ TRIASSIC } & KEUPER & & $89.5 \mathrm{~m}$ & $\begin{array}{l}\text { Shale, claystone, } \\
\text { sandstone }\end{array}$ & \\
\hline & \multirow{3}{*}{ MUSCHELKALK } & $\mathrm{U}$ & $30.9 \mathrm{~m}$ & $\begin{array}{l}\text { Clay, marls, marly } \\
\text { dolomite, limestone }\end{array}$ & Fe-Zn \\
\hline & & $\mathrm{M}$ & $32.7 \mathrm{~m}$ & Dolomite & Fe-Zn \\
\hline & & $\mathrm{L}$ & $120.2 \mathrm{~m}$ & $\begin{array}{l}\text { Dolomite, marly } \\
\text { limestone, } \\
\text { conglomerate }\end{array}$ & Fe-Zn-Pb \\
\hline & \multirow{2}{*}{ BUNTER } & $\mathrm{U}$ & $74.0 \mathrm{~m}$ & $\begin{array}{l}\text { Dolomite, dolomitic } \\
\text { marls, shale, } \\
\text { evaporate }\end{array}$ & $\mathrm{Fe}-\mathrm{Zn}-\mathrm{Pb}$ \\
\hline & & $\mathrm{M}+\mathrm{L}$ & $26.8 \mathrm{~m}$ & $\begin{array}{l}\text { Clayey sandstone, } \\
\text { sandstone argillite, } \\
\text { conglomerate }\end{array}$ & $\begin{array}{l}\mathrm{Cu}-\mathrm{Fe}- \\
\mathrm{Zn}-\mathrm{Pb}\end{array}$ \\
\hline PERMIAN & & & & Claystone & \\
\hline
\end{tabular}

Fig. 3. Stratigraphic profile of drill hole KW-3. U - Upper, M - Middle, L - Lower

The Bunter is represented by Lower Bunter and Roethian strata. The Lower Bunter rocks, which occur in all of the drill holes except KW-16, comprise clayey-sandstone terrigenous sediments containing intercalations of conglomerates and clayey-sandycarbonate beds typically characterized by red, maroon and green colours. The thicknesses of the Bunter strata range from several meters in KW-9 up to 30 meters in KM-81 and KW3. The Roethian rocks comprise various dolomite beds containing intercalations of shales and marls as well as minor intercalations and nests of gypsum and anhydrite. In comparison to the SE part of the Kraków-Częstochowa monocline, the thickness of the Roethian strata is greater and reaches $60-70 \mathrm{~m}$, decreaseing to several meters only in a small area north of the Miotek-Zielona deposit.

The Muschelkalk is composed of limestone and dolomite beds. The Lower Muschelkalk is divided into several units, i.e. the Gogolin, Gorażdże, Terebratula and Karchowice Beds which, in the uppermost part of the section, have a dolomiteconglomerate-clayey character. The lowermost part of the Muschelkalk, the Gogolin Beds, 
ranges between 50-70 $\mathrm{m}$ in thickness, decreasing towards the NE. These beds are typically crystalline, wavy limestones intercalated by conglomerates and clayey shales and containing a variety of faunal fragments. Dolomite beds occur in the uppermost part of the Muschelkalk and usually represent the Gorażdże, Terebratula and Karchowice Beds. The total thickness of these beds reaches $40 \mathrm{~m}$. The Middle Muschelkalk is represented by the Diplopora dolomite with a thickness varying from $20 \mathrm{~m}$ in the southern and eastern parts of the area to $60 \mathrm{~m}$ in the central part. This dolomite is characterized by high porosity and is commonly oolitic and conglomeratic. In the NE part of the area, limestone and oolitic limestone occur in place of the Diplopora dolomite. The upper parts of the Lower Muschelkalk and the Middle Muschelkalk strata host $\mathrm{Zn}-\mathrm{Pb}$ deposits and occurrences. In the Kalety deposit (Wielgomas 1959), the largest resources occur in the Middle Muschelkalk. It is difficult to define the boundary between the Middle and the Upper Muschelkalk as both are dolomitic in character. The Upper Muschelkalk is represented by the Tarnowice Beds which usually comprise marly dolomites lacking gypsum intercalations. The Tarnowice Beds are overlain by conglomerates, organodetritic limestones, dolomites and marls followed by clays, silty dolomites, mudstones and, locally, sandstones. The total thickness of the Upper Muschelkalk is $\sim 40 \mathrm{~m}$. The full Upper Muschelkalk sequence is present only in the northern part of the area whereas, in the southern part, these beds are not seen.

Keuper sediments, present over most of the area, are spotted, multi-coloured, clayey sandstones intercalated by carbonate beds. Their average thickness is $\sim 80$ meters, but they may reach 200 meters.

Younger sediments, for the most part, have been eroded away. Jurassic strata, up to $250 \mathrm{~m}$ thick, occur only in its eastern part. The entire area is covered with Quaternary deposits of varying thickness. These are conglomerates, sandstones, clays and soils which lie directly on the Triassic or Jurassic rocks.

\section{Ore mineralization}

Ore mineralization has been found in the Middle- and Lower Triassic rocks in the vicinity of Woźniki village (Fig. 2). This new find occurs at the same stratigraphic position as in other parts of the Upper Silesian district (Harańczyk 1962; Ziętek-Kruszewska 1978; Sass-Gustkiewicz 1997).

\subsection{Muschelkalk}

\subsubsection{Upper Muschelkalk}

In these strata, ore mineralization has been detected in KW-3 and KM-78 in the NW part of the area. Most common are pyrite and marcasite. They are dispersed in sparitic- and microsparitic dolomite and replace the matrix in dolomitic breccias where they form coatings on the breccia clasts. Single aggregates of iron sulphides reach up to $200 \mu \mathrm{m}$. Sphalerite is associated with Fe sulphides and forms the same structures. Single sphalerite aggregates reach $400 \mu \mathrm{m}$ though, in open spaces, they may be $2 \mathrm{~mm}$ in size. 


\subsubsection{Middle Muschelkalk}

In the study area, ore mineralization is common in the Diplopora dolomite, e.g. in KM-81, KW-3 and LW-9. Two stages of Fe sulphide formation have been recognized (Table 1). Pyrite is the major sulphide of Stage I. It occurs as dispersed grains and, locally, as massive accumulations. Pyrite and marcasite are also major constituents of Stage II (Table 1). They are developed as botryoidal forms and idiomorphic grains and are also very common in the oolitic dolomite. The Fe sulphides replace the inner- and outer parts of oolites and fill free spaces among them. The oolites are easily seen under a microscope because of the high reflectivity contrast between dolomite and sulphides. In the carbonate rocks characterized by high porosity, euhedral crystals of pyrite are very common. Sphalerite belonging to both stages occurs in porous, calcareous dolomite. Stage I sphalerite forms fine, disseminated grains whereas that of Stage II is coarsely-crystalline (Table 1). Galena occurs in the same way as sphalerite, e.g. in LW-9. Both sulphides can be identified in hand specimen.

Mineral succession in the Lower and Middle Triassic beds

\begin{tabular}{|c|c|c|}
\hline & Diagenetic & Hydrothermal \\
\hline & Stage I & Stage II \\
\hline Pyrite & + fine disseminated, framboids & + botryoidal \& coarse \\
\hline Thiosulphate & & + botryoidal \\
\hline Marcasite & & + botryoidal \& coarse \\
\hline Sphalerite & + finely disseminated & + coarse crystalline \\
\hline Tetrahedrite & & + \\
\hline Chalcopyrite & & + \\
\hline Bornite & & + \\
\hline Galena & & + \\
\hline Chalcocite & & + \\
\hline Covellite & & + \\
\hline Apatite & & + \\
\hline Barite & & + \\
\hline Dolomite & + metasomatic & + idiomorphic \\
\hline Calcite & & ++ \\
\hline
\end{tabular}

\subsubsection{Lower Muschelkalk}

These strata seem to be the most important horizon hosting $\mathrm{Zn}-\mathrm{Pb}$ mineralization. In comparison to other parts of the Muschelkalk, the concentration of ore minerals is higher, 
as is seen in KM-81, KW-3, LW-9, KW-16 and KW-9. The ore-mineral association occurs in calcareous dolomite which is usually brecciated. Iron sulphides (pyrite and marcasite), present in all samples studied, form aggregates up to several millimetres and thin veins. Pyrite also occurs in framboid structures. Iron sulphides characterise both stages. Fine grains of galena and sphalerite occur together with pyrite and marcasite (Table 1). Both $\mathrm{Pb}$ and $\mathrm{Zn}$ sulphides also form coarse crystalline grains $(<1 \mathrm{~mm})$ in dolomites characterized by visible porosity. Locally, inclusions of sphalerite occur in galena crystals. In the veins, Stage II sulphides are accompanied by younger calcite.

\subsection{Bunter}

A rich $\mathrm{Zn}-\mathrm{Pb}$ mineralization in the Lower Triassic strata has already been reported from the SE and E parts of the Silesian-Kraków ore district, e.g. in the Bolesław area (Nieć, Bąk 1993).

\subsubsection{Roethian}

In the NE part of the area, relatively rich (several vol.\%) sulphide mineralization has been found, e.g. in KW-16. In comparison to the Muschelkalk, the carbonate rocks of Roethian age contain lesser amounts of Fe sulphides. These sulphides concentrate in carbonate rocks in brecciated fragments (Stage I) and in cement (Stage II). They occur mostly in pore spaces, commonly as euhedral crystals $(<3 \mathrm{~mm})$ and as dispersed microscopic grains. Pyrite framboids are rare. Both sphalerite and galena occur in conglomerates, carbonate rocks and breccias. In hand specimen, these minerals line the surfaces of numerous pores and fissures in dolomite. They also occur as veinlets and dispersed grains, and together with calcite, cement conglomerates and dolomite breccias. In some places, Stage II galena and sphalerite replace earlier carbonate minerals.

\subsubsection{Lower Bunter}

Sandstones and conglomerates of the Lower Bunter are characterized not only by their red colour reflecting fine-grained, dispersed hematite, but also by polymetallic mineralization. Apart from the typical $\mathrm{Zn}-\mathrm{Pb}-\mathrm{Fe}$ association, copper sulphides have been detected here for the first time in this stratigraphic unit. The copper sulphide association consists of chalcopyrite, bornite, tetrahedrite, chalcocite and covellite (Fig. 4-11).

In KW-3, ore minerals were only detected in two samples collected from depths of $346.3 \mathrm{~m}$ (sample 38) and $348.7 \mathrm{~m}$ (sample 39). The former is a conglomerate characterized by the presence of the newly-discovered sulphide association in addition to pyrite, sphalerite and galena (Fig. 4-11). The latter is sandstone with traces of chalcopyrite, sphalerite and covellite. 


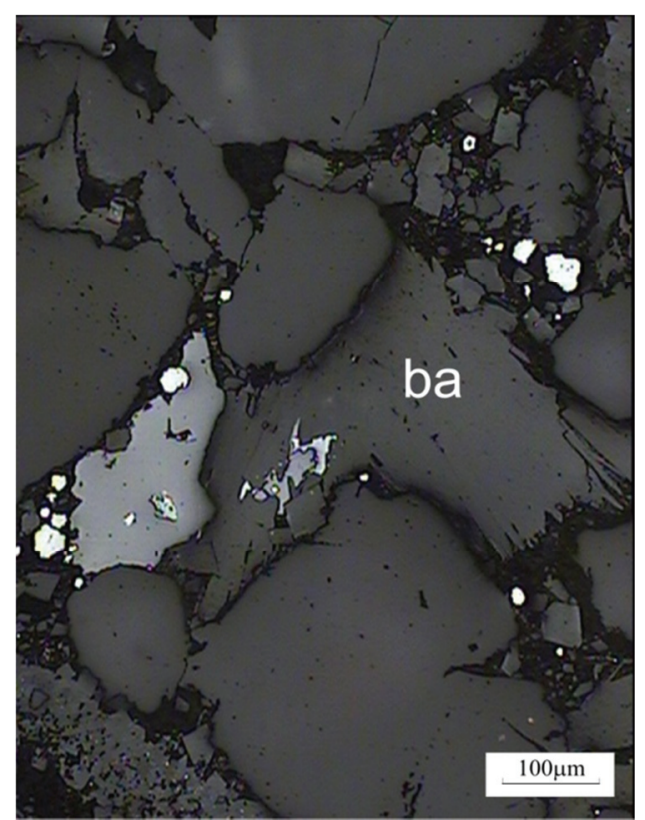

Fig. 4. Sphalerite (light-grey), galena (white), pyrite (yellow) and barite (ba) in sandstone matrix. Drill hole KW-3, sample 38, reflected light

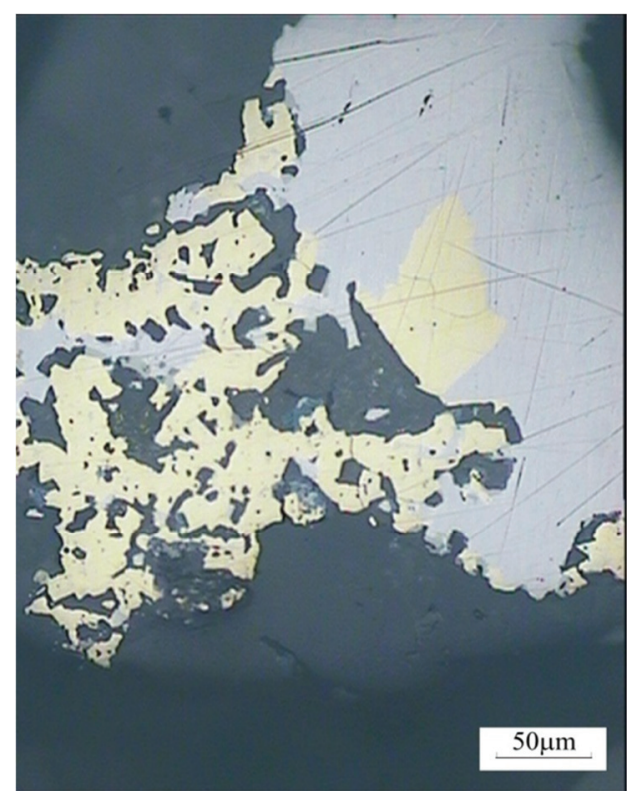

Fig. 6. An intergrowth of galena (white), chalcopyrite (yellow), covellite (blue) and tetrahedrite (grey) in conglomerate. Drill hole KW-3, sample 38, reflected light

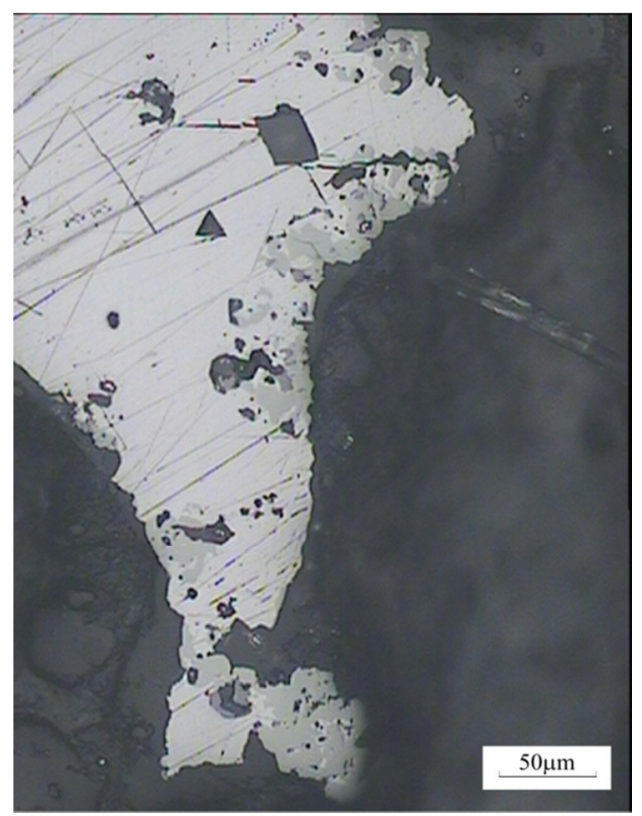

Fig. 5. An intergrowth of galena (white) and tetrahedrite (grey) in conglomerate. Drill hole KW-3, sample 38, reflected light

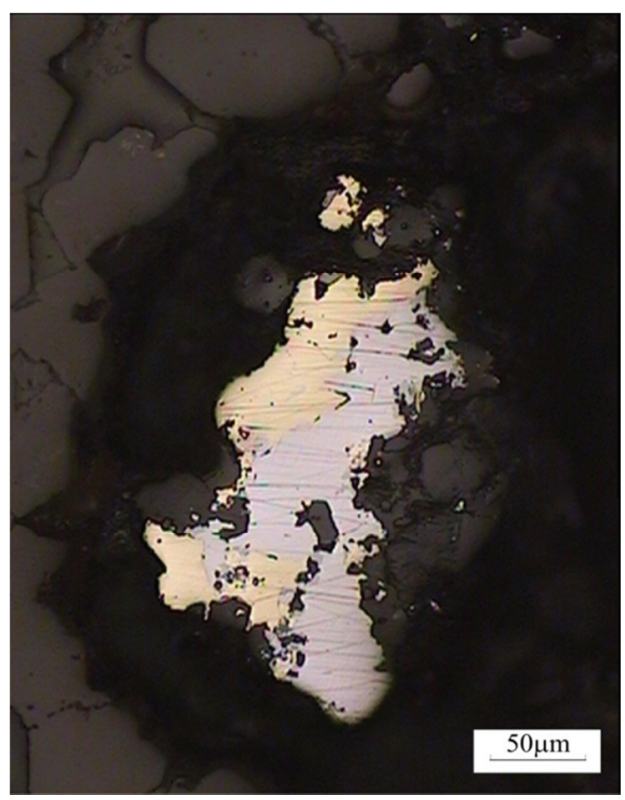

Fig. 7. An intergrowth of galena (white) and chalcopyrite (yellow) in conglomerate. Drill hole KW-3, sample 38, reflected light 


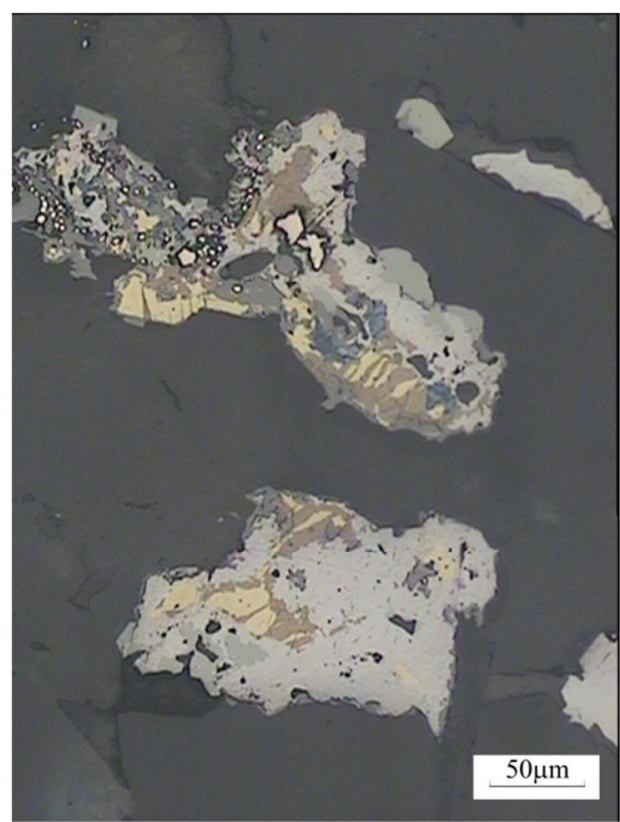

Fig. 8. Intergrowths of galena (white-grey), chalcopyrite (yellow), covellite (blue), bornite (brown), pyrite (white) and tetrahedrite (grey) in conglomerate. Drill hole KW-3, sample 38, reflected light

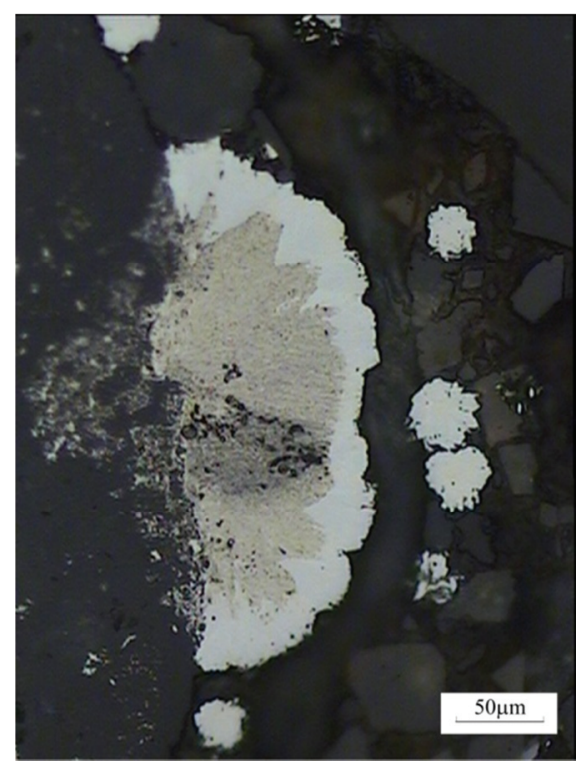

Fig. 10. Marcasite (white) replacing thiosulphate (cream). Dark grey is Fe sulphate. Drill hole KM-78, sample 10, reflected light

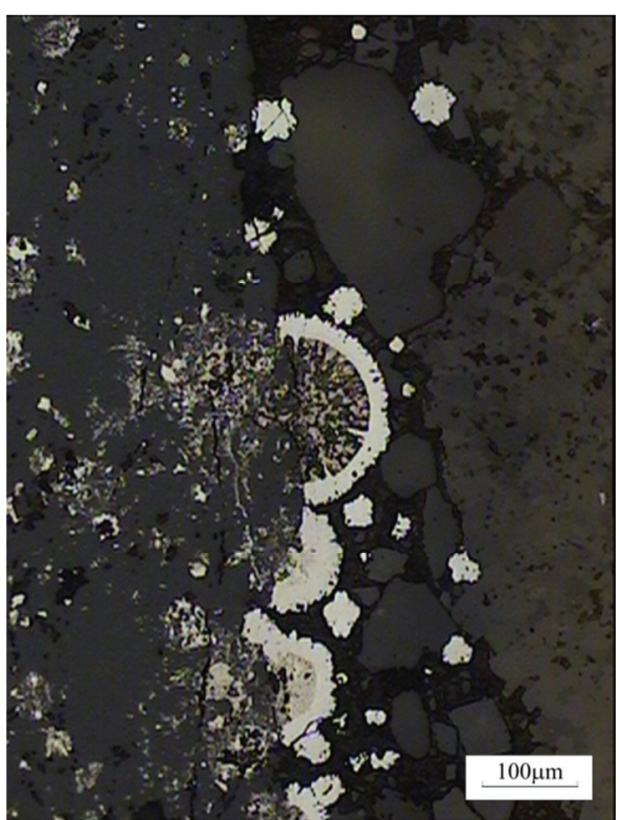

Fig. 9. A pseudomorph of $\mathrm{Fe}$ sulphides (white) after thiosulphates in sandstone. Drill hole KM78 , sample 10 , reflected light

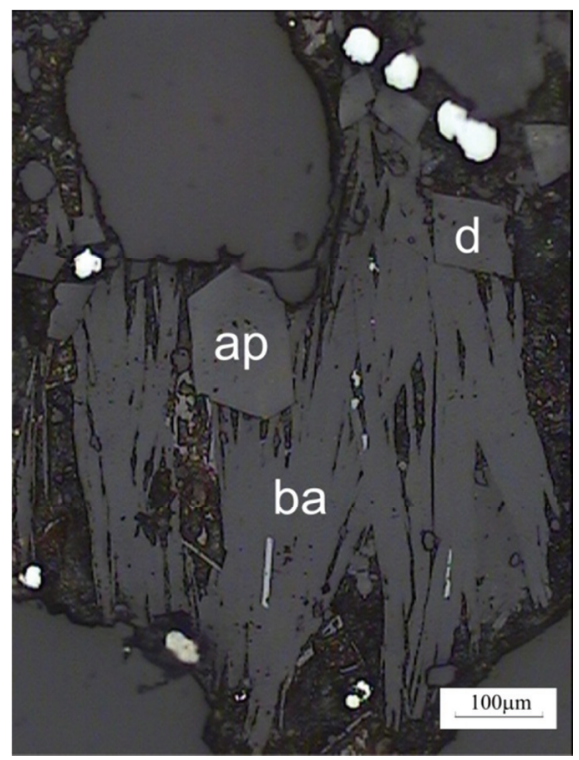

Fig. 11. Sphalerite (light-grey), pyrite (white), chalcopyrite (yellow), apatite crystal (ap) and dolomite (d) in a barite (ba) matrix of sandstone. Drill hole KW-3, sample 38, reflected light 
Pyrite and sphalerite define two genetic stages. In Stage I, they occur as small dispersed grains and, in Stage II, as veinlets, micronests and in conglomerate matrix comprising a sandy fraction and sulphates (Fig. 4). Sphalerite seems to be the older sulphide in Stage II as it is replaced by copper sulphides (Fig. 8). Such a sequence is also confirmed by the presence of $\mathrm{Zn}$ in copper sulphides (Tables 2-5). Chalcopyrite is the most common sulphide in this association. It occurs as intergrowths $(<150 \mu \mathrm{m}$ in size $)$ with other ore minerals and as individual grains $(<30 \mu \mathrm{m})$. Galena is the youngest sulphide and fills free spaces in micronests (Fig. 7, 8). The position of simple copper sulphides, i.e. chalcocite and covellite, can be explained by simultaneous processes of replacement and crystallization that strongly depend on Eh potential.

In KW-7, sulphides were encountered only in sandstone at a depth of $467.9 \mathrm{~m}$. The mineralization comprises mainly pyrite and chalcopyrite, the latter being sometimes intergrown with pyrite and sphalerite. The total amount of sulphides is $<1$ vol.\%. A similar association occurs in KM-78 drill core at a depth of $494.8 \mathrm{~m}$ (sample 10). Pyrite grains were recognized in the sandstone framework and in the clay-carbonate and carbonatesulphate cement of this rock. In the same sample, thiosulphates characterized by botryoidal structure and variable reflectivity were observed. The outer rim of the botryoidal thiosulphates is usually recrystallized to pyrite and marcasite (Fig. 9, 10) and shows higher reflectivity. Pyrite is the major sulphide in all the drill cores investigated and chalcopyrite is a minor component. They are accompanied by marcasite, sphalerite and galena.

\section{Chemical composition of the sulphides}

Selected sulphides from KW-3 and KM-78 were analysed using both WDS and EDS modes. The KW-3 samples represent the association containing copper sulphides, whereas the thiosulphates were investigated in those from KM-78. The results are presented in Tables 2-8.

The chemical composition of all the tetrahedrites analysed differs (Table 2) from the stoichiometric composition. It corresponds to the formula $\mathrm{Cu}_{8.1198-10.1153} \mathrm{Ag}_{0.0884} \mathrm{Fe}_{0.0325-0.2886} \mathrm{Zn}_{1.7433-2.4674} \mathrm{Sb}_{1.6718-2.9588} \mathrm{As}_{1.2558-2.8847} \mathrm{~S}_{13.0000}$ (silver was found in one analysis only). These tetrahedrites are characterized by lower copper contents (Makovicky, Karup Moller 1994), usually $<40 \mathrm{wt} \%$, and significant admixtures of zinc (7.15-9.08 wt\%) and arsenic (5.82-13.78 wt\%. As shown in Table 2, all of the tetrahedrites also contain small amounts of iron (0.11-1.03 wt\%) and some small admixtures of silver. The composition of these tetrahedrites resembles that of the tetrahedrites from the Myszków deposit (Piestrzyński, pers. comm. 2009). 
TABLE 2

Composition (WDS and EDS) of tetrahedrites from drill hole KW-3, sample 38

\begin{tabular}{|c|c|c|c|c|c|c|c|c|}
\hline Sample & S & $\mathrm{Fe}$ & $\mathrm{Zn}$ & $\mathrm{Cu}$ & $\mathrm{Ag}$ & As & $\mathrm{Sb}$ & Total \\
\hline \multirow{2}{*}{$\mathrm{A} / \mathrm{I}-1$} & 26.09 & 0.59 & 8.89 & 39.16 & \multirow{2}{*}{ n.d. } & 6.22 & 19.45 & \multirow{2}{*}{100.49} \\
\hline & 13.0000 & 0.1690 & 2.1736 & 9.8449 & & 1.3260 & 2.5532 & \\
\hline \multirow{2}{*}{$\mathrm{A} / \mathrm{I}-2$} & 26.08 & 0.63 & 8.94 & 39.36 & \multirow{2}{*}{ n.d. } & 6.58 & 19.25 & \multirow{2}{*}{100.84} \\
\hline & 13.0000 & 0.1807 & 2.1853 & 9.9008 & & 1.4040 & 2.5272 & \\
\hline \multirow{2}{*}{$\mathrm{A} / \mathrm{I}-4$} & 26.60 & 1.03 & 7.46 & 39.69 & \multirow{2}{*}{ n.d. } & 7.28 & 17.81 & \multirow{2}{*}{99.37} \\
\hline & 13.0000 & 0.2886 & 2.1853 & 8.1198 & & 1.5236 & 2.2919 & \\
\hline \multirow{2}{*}{ A/III-5 } & 26.53 & 0.29 & 9.01 & 38.92 & \multirow{2}{*}{ n.d. } & 7.45 & 17.34 & \multirow{2}{*}{99.54} \\
\hline & 13.0000 & 0.0806 & 2.1645 & 9.6239 & & 1.5613 & 2.2373 & \\
\hline \multirow{2}{*}{ A/III-7 } & 26.23 & 0.31 & 8.76 & 39.11 & \multirow{2}{*}{ n.d. } & 7.50 & 17.34 & \multirow{2}{*}{99.25} \\
\hline & 13.0000 & 0.0884 & 2.1281 & 9.7799 & & 1.5899 & 2.2633 & \\
\hline \multirow{2}{*}{$\mathrm{B} / \mathrm{I}-1$} & 25.85 & 0.24 & 7.91 & 39.65 & \multirow{2}{*}{ n.d. } & 7.60 & 16.85 & \multirow{2}{*}{98.10} \\
\hline & 13.0000 & 0.0689 & 1.9513 & 10.0633 & & 1.6354 & 2.2321 & \\
\hline \multirow{2}{*}{$\mathrm{B} / \mathrm{I}-2$} & 25.57 & 0.11 & 7.98 & 38.92 & \multirow{2}{*}{ n.d. } & 7.13 & 17.78 & \multirow{2}{*}{97.78} \\
\hline & 13.0000 & 0.0325 & 1.9890 & 9.9853 & & 1.5522 & 2.3803 & \\
\hline \multirow{2}{*}{$\mathrm{B} / \mathrm{I}-3$} & 26.09 & 0.13 & 8.31 & 39.81 & \multirow{2}{*}{ n.d. } & 6.44 & 19.28 & \multirow{2}{*}{100.17} \\
\hline & 13.0000 & 0.0364 & 2.0306 & 10.0100 & & 1.3728 & 2.5298 & \\
\hline \multirow{2}{*}{ B/I-4 } & 25.55 & 0.12 & 8.04 & 39.16 & \multirow{2}{*}{ n.d. } & 5.84 & 21.30 & \\
\hline & 13.0000 & 0.0338 & 2.0072 & 10.0529 & & 1.2714 & 2.8535 & 100.01 \\
\hline & 26.38 & 0.26 & 7.99 & 39.32 & & 8.33 & 17.20 & \\
\hline B/I-5 & 13.0000 & 0.0741 & 1.9305 & 9.7786 & n.d. & 1.7576 & 2.2334 & 99.64 \\
\hline $\mathrm{B} / \mathrm{L}-6$ & 25.63 & 0.19 & 8.19 & 39.52 & & 6.89 & 18.78 & \\
\hline$B / 1-6$ & 13.0000 & 0.0559 & 2.3580 & 10.1153 & n.d. & 1.4963 & 2.5090 & 99.27 \\
\hline $\mathrm{P} / \mathrm{I} 7$ & 26.13 & 0.64 & 7.15 & 38.72 & d & 7.56 & 18.32 & 0868 \\
\hline $\mathrm{B} / \mathrm{l}-1$ & 13.0000 & 0.1833 & 1.7433 & 9.7201 & n.d. & 1.6094 & 2.4011 & 98.68 \\
\hline & 26.55 & & 8.55 & 36.74 & & 7.19 & 20.98 & \\
\hline B/II-1 & 13.0000 & n.d. & 2.0540 & 9.0779 & n.d. & 1.5067 & 2.7053 & 100.00 \\
\hline & 26.83 & & 9.08 & 36.87 & & 9.73 & 17.49 & \\
\hline B/II-2 & 13.0000 & n.d. & 2.1580 & 9.0155 & n.d. & 2.0176 & 2.2321 & 100.00 \\
\hline $\mathrm{B} / \mathrm{II}-12$ & 26.57 & 0.35 & 8.58 & 37.74 & & 13.78 & 12.98 & \\
\hline $\mathrm{B} / \mathrm{II}-12$ & 13.0000 & 0.0988 & 2.0592 & 9.3184 & n.d. & 2.8847 & 1.6718 & 100.00 \\
\hline $\mathrm{D} / \mathrm{UI}$ & 26.37 & 0.13 & 8.62 & 37.01 & & 6.93 & 20.94 & (20 ח \\
\hline B/11-13 & 13.0000 & 0.0364 & 2.0852 & 9.2079 & n.d. & 1.4625 & 2.7196 & 100.00 \\
\hline $\mathrm{B} / \mathrm{V}-7$ & 25.56 & $n d$ & 8.58 & 38.58 & & 7.41 & 19.87 & 10000 \\
\hline B/V-1 & 13.0000 & n.d. & 2.4674 & 9.9021 & n.d. & 1.6133 & 2.6611 & 100.00 \\
\hline & 25.79 & & 8.34 & 37.18 & 0.59 & 5.82 & 22.29 & \\
\hline$B / V-8$ & 13.0000 & n.d. & 2.0618 & 9.4575 & 0.0884 & 1.2558 & 2.9588 & 100.00 \\
\hline
\end{tabular}

Upper figure in wt\%. Lower figure: atomic ratio calculated on the basis of 13 sulphur anions. n.d. - not detected. 
Composition (WDS and EDS) of bornites from drill hole KW-3, sample 38

\begin{tabular}{|c|c|c|c|c|c|c|c|c|}
\hline Sample & S & $\mathrm{Fe}$ & $\mathrm{Zn}$ & $\mathrm{Cu}$ & As & $\mathrm{Sb}$ & $\mathrm{Ag}$ & Total \\
\hline \multirow{2}{*}{$38 \mathrm{~B} / \mathrm{I}-2$} & 27.44 & 9.32 & 0.35 & 60.76 & \multirow{2}{*}{ n.d. } & \multirow{2}{*}{ n.d. } & 0.05 & \multirow{2}{*}{97.93} \\
\hline & 4.0000 & 0.7800 & 0.0252 & 4.4692 & & & 0.0024 & \\
\hline \multirow{2}{*}{$38 \mathrm{~B} / \mathrm{I}-4$} & 27.71 & 11.76 & 0.16 & 60.28 & \multirow{2}{*}{ n.d. } & 0.02 & 0.12 & \multirow{2}{*}{100.05} \\
\hline & 4.0000 & 0.9748 & 0.0112 & 4.3908 & & 0.0008 & 0.0052 & \\
\hline \multirow{2}{*}{$38 \mathrm{~B} / \mathrm{I}-5$} & 27.25 & 11.01 & 0.10 & 59.42 & \multirow{2}{*}{ n.d. } & \multirow{2}{*}{ n.d. } & 0.01 & \multirow{2}{*}{97.79} \\
\hline & 4.0000 & 0.9276 & 0.0072 & 4.4016 & & & 0.0004 & \\
\hline \multirow{2}{*}{$38 \mathrm{~B} / \mathrm{I}-6$} & 26.75 & 11.60 & 0.17 & 60.83 & \multirow{2}{*}{ n.d. } & 0.02 & 0.10 & \multirow{2}{*}{99.46} \\
\hline & 4.0000 & 0.9960 & 0.0124 & 4.5896 & & 0.0008 & 0.0044 & \\
\hline \multirow{2}{*}{$38 \mathrm{~B} / \mathrm{I}-7$} & 29.38 & 12.06 & 0.10 & 59.03 & 0.05 & \multirow{2}{*}{0.00} & 0.10 & \multirow{2}{*}{100.71} \\
\hline & 4.0000 & 1.0224 & 0.0064 & 4.0552 & 0.0032 & & 0.0040 & \\
\hline \multirow{2}{*}{$38 \mathrm{~B} / \mathrm{I}-8$} & 28.25 & 10.89 & 1.02 & 57.56 & \multirow{2}{*}{ n.d. } & 0.02 & 0.15 & \multirow{2}{*}{97.89} \\
\hline & 4.0000 & 0.0 .8852 & 0.0708 & 4.1124 & & 0.0008 & 0.0064 & \\
\hline \multirow{2}{*}{$38 \mathrm{~B} / \mathrm{I}-9$} & 29.81 & 10.91 & 0.15 & 58.93 & \multirow{2}{*}{ n.d. } & 0.05 & $n d$ & \multirow{2}{*}{99.76} \\
\hline & 4.0000 & 0.8408 & 0.0300 & 3.9900 & & 0.0016 & 111.u. & \\
\hline \multirow{2}{*}{$38 \mathrm{~B} / \mathrm{I}-10$} & 27.81 & 11.90 & 0.07 & 58.88 & \multirow{2}{*}{ n.d. } & \multirow{2}{*}{ n.d. } & 0.01 & \multirow{2}{*}{98.67} \\
\hline & 4.0000 & 0.9828 & 0.0052 & 4.2740 & & & 0.0004 & \\
\hline \multirow{2}{*}{$38 \mathrm{~B} / \mathrm{II}-3$} & 28.03 & 10.40 & n.d. & 61.57 & \multirow{2}{*}{ n.d. } & \multirow{2}{*}{ n.d. } & \multirow{2}{*}{ n.d. } & \multirow{2}{*}{100.00} \\
\hline & 4.0000 & 0.8520 & & 4.4336 & & & & \\
\hline \multirow{2}{*}{$38 \mathrm{~B} / \mathrm{II}-3 \mathrm{~b}$} & 27.03 & 9.96 & 1.2 & 58.69 & 3.12 & n.d. & $n d$ & 10000 \\
\hline & 4.0000 & 0.8460 & 0.0872 & 4.3828 & 0.1972 & & 11.u. & 100.00 \\
\hline $38 \mathrm{~B} / \mathrm{II}-4$ & 28.55 & 10.14 & 0.7 & 58.53 & 2.08 & nd & $n d$ & 10000 \\
\hline $38 \mathrm{~B} / 11-4$ & 4.0000 & 0.8160 & 0.0480 & 4.1384 & 0.1248 & n.a. & & 100.00 \\
\hline
\end{tabular}

Upper figure in wt\%. Lower figure - atomic ratio calculated on the basis of four anions. n.d. - not detected.

Bornites from the Lower Bunter show admixtures of zinc $(<1.2 \mathrm{wt} \%)$ and of arsenic ranging between 2.08-3.12 wt\% (Table 3), which are not typical for this mineral (Piestrzyński 1992). The bornites also show a small admixture of silver (0.01-0.15 wt\%). Their chemical composition corresponds to $\mathrm{Cu}_{3.9900-4.5896} \mathrm{Ag}_{0.0004-0.0032} \mathrm{Fe}_{0.7800-0.9960} \mathrm{Zn}_{0.0052-}$ ${ }_{0.0872} \mathrm{~S}_{4}$. The $\mathrm{Zn}$ content of the bornites compares with that of bornites from Myszków (Piestrzyński, pers. comm. 2009).

In all of the chalcopyrites analysed, the content of copper is variable and ranges from 34.34-35.60 wt\% (Table 4). Their iron contents are relatively low compared to the stoichiometric composition; part of Fe is replaced by $\mathrm{Zn}$ (Table 4). Copper and iron may also be replaced by $\mathrm{Ag}$ in quantities ranging from below the detection limit to $0.61 \mathrm{wt} \%$. Some of the chalcopyrites also show small admixtures of $\mathrm{Sb}$ and As. The chemical composition of this mineral is $\mathrm{Cu}_{0.9540-1.0406} \mathrm{Ag}_{0.0004-0.0108} \mathrm{Fe}_{0.9048-0.9760} \mathrm{Zn}_{0.0034-1.0398} \mathrm{~S}_{2}$. 
TABLE 4

Composition (WDS and EDS) of chalcopyrite from drill hole KW-3, sample 38

\begin{tabular}{ccccccccc}
\hline Sample & $\mathrm{S}$ & $\mathrm{Fe}$ & $\mathrm{Zn}$ & $\mathrm{Cu}$ & $\mathrm{Sb}$ & $\mathrm{As}$ & $\mathrm{Ag}$ & Total \\
\hline \multirow{2}{*}{ 38B/I-11 } & 35.99 & 28.87 & & 34.87 & 0.04 & 0.03 & n.d. & 99.80 \\
& 2.0000 & 0.9210 & n.d. & 0.9778 & 0.0006 & 0.0008 & & \\
38B/I-12 & 34.15 & 28.50 & 0.12 & 34.51 & 0.28 & 0.52 & n.d. & 98.09 \\
& 2.0000 & 0.9582 & 0.0034 & 1.0198 & 0.0044 & 0.0130 & & \\
38B/I-14 & 34.07 & 28.65 & 0.41 & 35.13 & 0.10 & 0.67 & 0.02 & 99.04 \\
& 2.0000 & 0.9656 & 0.0118 & 1.0406 & 0.0016 & 0.0168 & 0.0004 & \\
38B/I-15 & 35.96 & 29.62 & 0.30 & 34.34 & & & 0.06 & \\
& 2.0000 & 0.9458 & 0.0082 & 0.9638 & n.d. & 0.00 & 0.0010 & 100.28 \\
38B/I-16 & 34.86 & 29.63 & 0.21 & 35.60 & 0.01 & 0.04 & 0.07 & \\
& 2.0000 & 0.9760 & 0.0058 & 1.0308 & 0.0002 & 0.0010 & 0.0012 & 100.42 \\
38B/II-8 & 36.50 & 29.0 & & 34.50 & & & & \\
& 2.0000 & 0.9124 & n.d. & 0.9540 & n.d. & n.d. & n.d. & 100.00 \\
38B/IV-1 & 34.06 & 26.84 & 3.40 & 35.09 & & & & \\
& 2.0000 & 0.9048 & 1.0398 & 1.0398 & n.d. & n.d. & 0.61 & 100.00 \\
38B/V-9 & 34.77 & 28.28 & 1,77 & 34.80 & & & 0.0108 & \\
& 2.0000 & 0.9340 & 0.0500 & 1.0102 & n.d. & n.d. & 0.38 & \\
& & & & & & 0.0064 & 100.00 \\
\hline
\end{tabular}

Upper figure in $\mathrm{wt} \%$. Lower figure - atomic ratio calculated on the basis of two anions. n.d. - not detected.

TABLE 5

Composition (EDS) of covellite from drill hole KW-3, sample 38

\begin{tabular}{ccccccc}
\hline Sample & $\mathrm{S}$ & $\mathrm{Fe}$ & $\mathrm{Zn}$ & $\mathrm{Cu}$ & $\mathrm{As}$ & Total \\
\hline 38B/II-5 & 30.91 & n.d. & 0.42 & 65.58 & 3.09 & 100.00 \\
& 0.9340 & & 0.0062 & 1.0000 & 0.0399 & \\
$38 \mathrm{~B} / \mathrm{II}-9$ & 30.97 & n.d. & 1.29 & 64.82 & 2.92 & 100.00 \\
& 0.9469 & & 0.0193 & 1.0000 & 0.0382 & \\
$38 \mathrm{~B} / \mathrm{II}-14$ & 31.74 & 0.46 & n.d. & 66.52 & 1.29 & 100.00 \\
& 0.9456 & 0.0078 & & 1.0000 & 0.0164 & \\
\hline
\end{tabular}

Upper figure in $\mathrm{wt} \%$. Lower figure - atomic ratio calculated on the basis of one $\mathrm{Cu}$ cation. n.d. - not detected

The covellites analysed are of almost standard composition though their sulphur contents are usually low compared with the chemical formula. Sulphur is probably replaced by small amounts of arsenic. Small amounts of $\mathrm{Zn}$ and Fe were also detected (Table 5). 
Only one grain of sphalerite was suitable for EDS analysis. It shows a high content of $\mathrm{Cu}(7.34 \mathrm{wt} \%)$ and also admixtures of $\mathrm{Cd}(0.75 \mathrm{wt} \%)$ and $\mathrm{Fe}(1.41 \mathrm{wt} \%)$. This grain is opaque, not translucent, reflecting the presence of $\mathrm{Cu}$ (Piestrzyński 1992). Although the copper content is unusually high, "chalcopyrite disease" is not evident in sphalerite; there are no $\mathrm{CuFeS}_{2}$ inclusions. This requires further study. Sphalerites with chalcopyrite inclusions typically show lower copper contents.

In galena grains, small admixtures of $\mathrm{Zn}(0.27-1.23 \mathrm{wt} \%), \mathrm{Fe}(0.17-1.30 \mathrm{wt} \%)$, $\mathrm{Cu}(0.04-1.75 \mathrm{wt} \%)$ and $\mathrm{Ag}(0.34-0.79 \mathrm{wt} \%)$ have been found, and in some, very small amounts of $\mathrm{As}$ and $\mathrm{Sb}$ (Table 6). Atomic correlation of these elements excludes the possibility that these admixtures reflect submicroscopic inclusions of tetrahedrite. The atomic proportions of the galena correspond to the composition $\mathrm{Pb}_{0.8144-1.0054} \mathrm{Zn}_{0.0455-0.0102} \mathrm{Fe}_{0.0074-0.0565} \mathrm{Ag}_{0.0101-0.0149} \mathrm{Cu}_{0.0015-0.0667} \mathrm{~S}_{2.0000} \mathrm{As}_{0.0005-0.0152} \mathrm{Sb}_{0.0065-0.0077}$.

TABLE 6

Composition (WDS and EDS) of galena from drill hole KW-3, sample 38

\begin{tabular}{|c|c|c|c|c|c|c|c|c|c|}
\hline Sample & $\mathrm{S}$ & $\mathrm{Pb}$ & $\mathrm{Ag}$ & As & $\mathrm{Zn}$ & $\mathrm{Cu}$ & $\mathrm{Sb}$ & $\mathrm{Fe}$ & Total \\
\hline \multirow{2}{*}{ 38A/I-3 } & 13.22 & 81.98 & \multirow{2}{*}{ n.d. } & 0.04 & 0.34 & 1.75 & 0.35 & 1.30 & \multirow{2}{*}{98.98} \\
\hline & 1.0000 & 0.9597 & & 0.0005 & 0.0136 & 0.0667 & 0.0070 & 0.0565 & \\
\hline \multirow{2}{*}{ 38A/I-10 } & 13.25 & 84.07 & \multirow{2}{*}{ n.d. } & 0.10 & 1.23 & & 0.33 & 0.32 & \multirow{2}{*}{99.30} \\
\hline & 1.0000 & 0.9821 & & 0.0031 & 0.0455 & & 0.0065 & 0.0138 & \\
\hline \multirow{2}{*}{ 38A/III-1 } & 12.95 & 84.13 & \multirow{2}{*}{ n.d. } & \multirow{2}{*}{ n.d. } & 0.27 & 0.04 & 0.38 & 0.17 & \multirow{2}{*}{97.90} \\
\hline & 1.0000 & 1.0054 & & & 0.0102 & 0.0015 & 0.0077 & 0.0074 & \\
\hline \multirow{2}{*}{ 38A/III-3 } & 12.99 & 83.29 & \multirow{2}{*}{ n.d. } & 0.10 & 0.94 & 0.66 & 0.37 & 0.39 & \multirow{2}{*}{98.70} \\
\hline & 1.0000 & 0.9923 & & 0.0032 & 0.0355 & 0.0257 & 0.0074 & 0.0173 & \\
\hline \multirow{2}{*}{$38 \mathrm{~A} / \mathrm{III}-4$} & 12.94 & 83.99 & \multirow{2}{*}{ n.d. } & 0.13 & 0.87 & 1.40 & 0.37 & 0.27 & \multirow{2}{*}{99.97} \\
\hline & 1.0000 & 1.0045 & & 0.0042 & 0.0330 & 0.0545 & 0.0074 & 0.0119 & \\
\hline \multirow{2}{*}{$38 \mathrm{~B} / \mathrm{IV}-3$} & 15.73 & 83.25 & 0.54 & 0.48 & \multirow{2}{*}{ n.d. } & \multirow{2}{*}{ n.d. } & \multirow{2}{*}{ n.d. } & \multirow{2}{*}{ n.d. } & \multirow{2}{*}{100.00} \\
\hline & 1.0000 & 0.8144 & 0.0101 & 0.0130 & & & & & \\
\hline \multirow{2}{*}{$38 \mathrm{~B} / \mathrm{IV}-4$} & 15.82 & 83.62 & n.d. & 0.56 & \multirow{2}{*}{ n.d. } & \multirow{2}{*}{ n.d. } & \multirow{2}{*}{ n.d. } & \multirow{2}{*}{ n.d. } & \multirow{2}{*}{100.00} \\
\hline & 1.0000 & 0.8180 & & 0.0152 & & & & & \\
\hline \multirow{2}{*}{$38 \mathrm{~B} / \mathrm{V}-5$} & 15.76 & 83.64 & 0.34 & 0.26 & \multirow{2}{*}{ n.d. } & \multirow{2}{*}{ n.d. } & \multirow{2}{*}{ n.d. } & \multirow{2}{*}{ n.d. } & \multirow{2}{*}{100.00} \\
\hline & 1.0000 & 0.8216 & 0.0065 & 0.0071 & & & & & \\
\hline \multirow{2}{*}{$38 \mathrm{~B} / \mathrm{V}-6$} & 15.71 & 83.50 & 0.79 & & & & n.c. & n.d. & 100.00 \\
\hline & 1.0000 & 0.8224 & 0.0149 & $110 . \mathrm{c}$ & 11.d. & 11.d. & 11.u. & 11.0. & \\
\hline
\end{tabular}

Upper figure in $\mathrm{wt} \%$. Lower figure - atomic ratio calculated on the basis of one anion. n.d. - not detected. 
Microprobe compositions of iron sulphides analysed, i.e. Stage II pyrites, approximate the chemical formula $\mathrm{FeS}_{2}$. Some grains of $\mathrm{FeS}_{2}$ show lower $\mathrm{Fe}$ contents (Table 7) with $\mathrm{Zn}(0.06-0.41 \mathrm{wt} \%), \mathrm{Cu}(0.76-1.04 \mathrm{wt} \%)$ and $\mathrm{Ag}(0.03-0.06 \mathrm{wt} \%)$ replacing iron. The pyrites have the composition $\mathrm{Fe}_{0.9180-0.9666} \mathrm{Cu}_{0.0146-0.0196} \mathrm{Zn}_{0.0010-0.0072} \mathrm{Ag}_{0.0006-0.0008} \mathrm{~S}_{2}$.

TABLE 7

Composition (WDS) of pyrite from drill hole KW-3, sample 38

\begin{tabular}{ccccccccc}
\hline Sample & $\mathrm{S}$ & $\mathrm{Fe}$ & $\mathrm{Zn}$ & $\mathrm{Cu}$ & $\mathrm{Sb}$ & $\mathrm{As}$ & $\mathrm{Ag}$ & Total \\
\hline \multirow{2}{*}{ 38B/I-17 } & 56.19 & 44.93 & 0.41 & 1.04 & 0.04 & 0.02 & n.d. & 102.63 \\
& 2.0000 & 0.9180 & 0.0072 & 0.0188 & 0.0006 & 0.0006 & & \\
38B/I-18 & 52.92 & 44.55 & 0.06 & 0.76 & 0.03 & 0.00 & 0.06 & 98.38 \\
& 2.0000 & 0.9666 & 0.0010 & 0.0146 & 0.0004 & & 0.0008 & \\
38B/I-19 & 55.29 & 44.63 & 0.08 & 0.81 & & & 0.03 & 100.83 \\
& 2.0000 & 0.9268 & 0.0014 & 0.0148 & n.d. & 0.00 & 0.0006 & \\
38B/I-20 & 52.72 & 45.39 & 0.32 & 1.02 & 0.05 & 0.01 & & \\
& 2.0000 & 0.9886 & 0.0060 & 0.0196 & 0.0004 & 0.0002 & n.d. & 99.51 \\
\hline
\end{tabular}

Upper figure in $\mathrm{wt} \%$. Lower figure - atomic ratio calculated on the basis of two anions. n.d. - not detected.

Botryoidal grains of Fe sulphides in sample 10 from KM-78 show variable chemical composition (Table 8). These belong to Stage II. The internal parts of the grains are usually occupied by fibrous intergrowths of recrystalized Fe sulphides, thiosulphates and sulphates. The sulphates are a relatively dark member of these structures in reflected light. The grains characterized by low reflectivity are mixtures of marcasite, pyrite and thiosulphates (Fig. 9, 10). EDS analysis of the thiosulphates shows their variable oxygen content (3.59$16.26 \mathrm{wt} \%$ ). As a rule, crystals with high reflectivity have low oxygen contents (Table 8) and those with low reflectivity, the opposite. The crystals with high reflectivity are the Fe sulphides, with marcasite being the dominant phase (Fig. 9, 10). Such phenomena were described by Kucha and Viaene (1993) in samples from the Orzeł Biały mine, also in Upper Silesia. In general, the chemical formula of these compounds corresponds to $\left(\mathrm{Fe}_{0.9191-1.2759} \mathrm{Cu}_{0.0057-0.0328} \mathrm{Zn}_{0.0056-0.0129} \mathrm{Ni}_{0.0050-0.0255}\right)\left(\mathrm{S}_{2.0000} \mathrm{As}_{0.0134-0.0579}\right) \mathrm{O}_{0.2768-1.6819} . \quad$ An oxygen deficit in the thiosulphates is probably the result of their recrystalization in a reducing environment; $\mathrm{FeS}_{2} \mathrm{O}_{3}$ changed to $\mathrm{FeS}_{2}$. The thiosulphates analysed are anisotropic and bireflectant.

Microscopic and EDS analyses confirm the presence of coarsely-crystalline, needleshaped barite and idiomorphic apatite crystals (Fig. 11) in samples from KW-3. The barite grains have high concentrations of $\mathrm{Sr}(4.92 \mathrm{wt} \%), \mathrm{Pb}(0.23 \mathrm{wt} \%), \mathrm{Cu}(1.05 \mathrm{wt} \%)$ and $\mathrm{As}$ (3.68 wt\%). The idiomorphic shape of the F-bearing apatite $(1.95 \mathrm{wt} \% \mathrm{~F})$ is rather unusual in sediments. The metals in the barite, the habit of the apatite, and the crystallization of both in open spaces, point to a hydrothermal origin for these minerals. 
Composition (EDS) of thiosulphates from drill hole KM-78, sample 10

\begin{tabular}{|c|c|c|c|c|c|c|c|c|c|c|}
\hline Sample & $\mathrm{O}$ & $S$ & $\mathrm{Fe}$ & $\mathrm{Cu}$ & $\mathrm{Zn}$ & $\mathrm{Ni}$ & As & K & $\mathrm{Ca}$ & Total \\
\hline \multirow{2}{*}{ 10A-1 } & 3.59 & 51.99 & 43.10 & 0.87 & 0.45 & \multirow{2}{*}{ n.d. } & \multirow{2}{*}{ n.d. } & \multirow{2}{*}{ n.d. } & \multirow{2}{*}{ n.d. } & \multirow{2}{*}{100.00} \\
\hline & 0.2768 & 2.0000 & 0.9520 & 0.0169 & 0.0085 & & & & & \\
\hline \multirow{2}{*}{$10 \mathrm{~A}-2$} & 3.64 & 51.50 & 44.20 & 0.29 & 0.36 & \multirow{2}{*}{ n.d. } & \multirow{2}{*}{ n.d. } & \multirow{2}{*}{ n.d. } & \multirow{2}{*}{ n.d. } & \multirow{2}{*}{100.00} \\
\hline & 0.2833 & 2.0000 & 0.9855 & 0.0057 & 0.0068 & & & & & \\
\hline \multirow{2}{*}{$10 \mathrm{~A}-3$} & 3.67 & 51.72 & 41.40 & 1.30 & 0.65 & 1.26 & \multirow{2}{*}{ n.d. } & \multirow{2}{*}{ n.d. } & \multirow{2}{*}{ n.d. } & \multirow{2}{*}{100.00} \\
\hline & 0.2844 & 2.0000 & 0.9191 & 0.0254 & 0.0123 & 0.0267 & & & & \\
\hline \multirow{2}{*}{$10 \mathrm{~A}-4$} & 7.81 & 47.3 & 40.30 & 1.05 & 0.40 & 0.79 & 0.79 & 1.48 & \multirow{2}{*}{ n.d. } & \multirow{2}{*}{100.00} \\
\hline & 0.6605 & 2.0000 & 0.9765 & 0.0223 & 0.0083 & 0.0183 & 0.0142 & 0.0513 & & \\
\hline \multirow{2}{*}{$10 \mathrm{~A}-5$} & 7.2 & 47.77 & 40.26 & 1.43 & 0.63 & 0.89 & 0.62 & 1.12 & \multirow{2}{*}{ n.d. } & \multirow{2}{*}{100.00} \\
\hline & 0.6100 & 2.0000 & 0.9678 & 0.0302 & 0.0129 & 0.0204 & 0.0168 & 0.0384 & & \\
\hline \multirow{2}{*}{$10 \mathrm{~A}-6$} & 8.18 & 47.50 & 39.69 & 1.00 & 0.60 & 0.90 & 0.79 & 1.33 & \multirow{2}{*}{ n.d. } & \multirow{2}{*}{100.00} \\
\hline & 0.6903 & 2.0000 & 0.9595 & 0.0212 & 0.0124 & 0.0207 & 0.0142 & 0.0459 & & \\
\hline \multirow{2}{*}{$10 \mathrm{~A}-7$} & 13.92 & 37.6 & 41.06 & 0.99 & 0.32 & 0.79 & 2.55 & 2.69 & \multirow{2}{*}{ n.d. } & \multirow{2}{*}{100.00} \\
\hline & 1.4807 & 2.0000 & 1.2513 & 0.0266 & 0.0083 & 0.0230 & 0.0579 & 0.1171 & & \\
\hline \multirow{2}{*}{$10 \mathrm{~A}-8$} & 15.15 & 36.86 & 40.96 & 0.95 & 0.26 & 0.56 & 2.04 & 3.23 & \multirow{2}{*}{ n.d. } & 10000 \\
\hline & 1.6474 & 2.0000 & 1.2759 & 0.0261 & 0.0070 & 0.0165 & 0.0473 & 0.1437 & & 100.00 \\
\hline $10 A_{-}$ & 15.48 & 36.89 & 39.98 & 1.02 & 0.44 & 075 & 2.47 & 2.96 & nd & 10000 \\
\hline 10A-S & 1.6819 & 2.0000 & 1.2445 & 0.0280 & 0.0116 & 0.0223 & 0.0574 & 0.1316 & & 100.00 \\
\hline 104 & 3.68 & 52.19 & 41.89 & 0.61 & 0.5 & 0.24 & 0.82 & n.d. & & \\
\hline $10 \mathrm{~A}-10$ & 0.2826 & 2.0000 & 0.9217 & 0.0118 & 0.0107 & 0.0050 & 0.0134 & & n.a. & 100.00 \\
\hline $10 \mathrm{~A}_{-}$ & 12.39 & 43.09 & 38.17 & 1.11 & 0.43 & 0.65 & 2.67 & 1.49 & & \\
\hline $10 A-11$ & 1.1525 & 2.0000 & 1.0172 & 0.0260 & 0.0098 & 0.0165 & 0.0530 & 0.0567 & & 100.00 \\
\hline & 16.26 & 40.29 & 37.13 & 1.31 & 0.23 & 0.94 & 2.01 & 0.47 & 1.38 & 10000 \\
\hline $10 \mathrm{~A}-12$ & 1.6177 & 2.0000 & 1.0583 & 0.0328 & 0.0056 & 0.0255 & 0.0427 & 0.0191 & 0.0548 & 100.00 \\
\hline
\end{tabular}

Upper figure in wt\%. Lower figure - atomic ratio calculated on the basis of two sulphur anions. n.d. - not detected.

\section{Summary and conclusions}

Discussion on the genesis of the $\mathrm{Zn}-\mathrm{Pb}$ deposit has a long history (Gruszczyk 1956, 1978; Gałkiewicz 1966, 1978; Bogacz et al. 1975; Ekiert 1957; Przeniosło 1971; Smolarska 1974; Sass-Gustkiewicz 1996). The source of the ore fluids and their relation to tectonic events were discussed by Górecka (1972) who related different associations of ore minerals to Caledonian, Variscan and Alpine orogenic events. The ore mineralization discussed in the present paper crosscuts stratigraphic and lithological boundaries. In the horizon characterized previously by the presence of $\mathrm{Zn}-\mathrm{Pb}$-Fe sulphides only, a new association of $\mathrm{Cu}$ sulphides and sulphosalts accompanied by barite has been described. The discovery of copper mineralization in the western part of the Upper Silesian ore district should prompt further exploration. 
This study has shown that the Lower Bunter strata contain traces of ore mineralization beneath and different from the typical $\mathrm{Zn}-\mathrm{Pb}$ ores in the Lower Muschelkalk. The copper sulphide and sulphosalt mineralization represented by chalcopyrite, bornite, chalcocite, tetrahedrite and covellite (Fig. 5-8), and coexisting with subordinate amounts of $\mathrm{Zn}-\mathrm{Pb}$ sulphides, suggests a similar timing of mineralisation for all (Table 1).

The fine-grained sphalerite and pyrite occurring as disseminated grains are ascribed to the diagenetic stage (Stage I). The nest-type polymetallic association is typical of a hydrothermal origin (Stage II). However, the metal source of both assemblages was probably the same. Many trace metals are present in all of the ore minerals. The sulphides precipitated from the same fluid, but in different times and in different environments (reflecting $\mathrm{pH}$ and Eh potential). Common minor barite is usually positioned after the formation of the sulphide association, and before calcite, in the mineral succession of the $\mathrm{Zn}-\mathrm{Pb}$ deposits of Upper Silesia (Sass-Gustkiewicz et al. 2000). In contrast, the presence of coarse-crystalline barite suggests a different position for this mineral, i.e. prior to the crystallisation of the sulphides (Table 1). The arsenic in the autigenic barite confirms the position of barite in the mineral succession proposed here (Table 1).

High levels of $\mathrm{Zn}$ in $\mathrm{Cu}$ sulphides and of copper in $\mathrm{Zn}-\mathrm{Pb}$ sulphides may suggest a common source for the metal-transporting fluids. High levels of $\mathrm{Zn}$, and minor Fe and As in the tetrahedrites and $\mathrm{Zn}$ in the bornites, confirm previous conclusions recognising Palaeozoic strata as the likely metal source (Górecka 1972; Kozłowski, Górecka 1993). Tetrahedrite and $\mathrm{Cu}$ sulphides in the $\mathrm{Zn}-\mathrm{Pb}$ stratabound horizon (MVT deposit) are a new mineral association that can be related to a metal source located within the underlying Palaeozoic strata.

Acknowledgements. The author would like to thank Mr. Adam Gawel, M.Sc., from the AGH-UST, Faculty of Geology, Geophysics and Environmental Protection, for EDS measurements. The author is grateful to the anonymous reviewers for their excellent work and language correction. The work was partially financed by AGH research project B.S. 11.11.140.562.

\section{References}

Bogacz, K., Dżułyński, S., Harańczyk, C., \& Sobczyński, P. (1975). Origin of the Ore-Bearing Dolomite in the Triassic of the Cracow-Silesian Pb-Zn Ore District. Rocznik Polskiego Towarzystwa Geologicznego, 45, 139155 .

Bukowy, S. (1964). Nowe poglądy na budowę NE obrzeżenia GZW. Biuletyn Instytutu Geologicznego, 184, 5-20.

Ekiert, F. (1957). Geneza śląsko-krakowskich złóż cynkowo-ołowiowych. Przegląd Geologiczny, 7, 322-325.

Ekiert, F. (1971). Budowa geologiczna podpermskiego podłoża NE obrzeżenia GZW. Prace Instytutu Geologicznego, 66, 5-77.

Gałkiewicz, T. (1966). Geneza śląsko-krakowskich złóż cynkowo-ołowiowych. Rudy i Metale Nieżelazne, 6, $283-$ 290.

Gałkiewicz, T. (1978). Hipoteza endogenicznego pochodzenia złóż. In Poszukiwanie rud cynku i ołowiu na obszarze śląsko-krakowskim. Prace Instytutu Geologicznego, LXXXIII, 301-307.

Górecka, E. (1972). Mineralizacja kruszcowa w utworach paleozoicznych północno-wschodniej części obszaru śląsko-krakowskiego. Acta Geologica Polonica, 22(2), 275-326.

Górecka, E. (1993). Geological setting of the Silesian-Cracow Zn-Pb deposits. Kwartalnik Geologiczny, $37,127-$ 145. 
Gruszczyk, H. (1956). O wykształceniu i genezie śląsko-krakowskich złóż cynkowo-ołowiowych. Biuletyn Instytutu Geologicznego, 90, 186.

Gruszczyk, H. (1978). Hipoteza poligenicznego pochodzenia złoża. In Poszukiwanie rud cynku i ołowiu na obszarze śląsko-krakowskim. Prace Instytutu Geologicznego, LXXXIII, 307-311.

Harańczyk, C. (1962). Mineralogia kruszców śląsko-krakowskich złóż cynku i ołowiu. Prace Geologiczne Komisji Nauk Geologicznych PAN Oddz. w Krakowie, 8, 98.

Herbich, E. (1981). A tectonic analysis of the fault network of the Upper Silesia Coal Basin. Annales Societatis Geologorum Poloniae, 51, 383-434.

Kasprzak, R. (1969). Budowa geologiczna i opracowanie wyników badań w rejonie Trzebiesławice-Niegowonice. Centralne Archiwum Geologiczne PIG.

Kasprzak, R., \& Kerber, B. (1979). Zmienność rozmieszczenia mineralizacji Zn-Pb, w skałach węglanowych triasu północnego obrzeżenia GZW. Kwartalnik Geologiczny, 23(2), 363-380.

Kerber, B. (1977). Charakterystyka złóż w rejonie tarnogórskim. Charakterystyka rud Zn-Pb na obszarze śląskokrakowskim (cz. 2). Centralne Archiwum Geologiczne PIG.

Kozłowski, A., \& Górecka, E. (1993). Sphalerite origin in the Olkusz mining district: fluid inclusion model. Kwartalnik Geologiczny, 37(2), 291-305.

Kucha, H., \& Viaene, W. (1993). Compounds with mixed and intermediate sulfur valences as precursors of banded sulfides in carbonate-hosted $\mathrm{Zn}-\mathrm{Pb}$ deposits in Belgium and Poland. Mineralium Deposita, 28(1), 1321.

Makovicky, E., \& Karup Moller, S. (1994). Exploratory studies on substitution of minor elements in synthetic tetrahedrite. Part I. Substitution by $\mathrm{Fe}, \mathrm{Zn}, \mathrm{Co}, \mathrm{Ni}, \mathrm{Mn}, \mathrm{Cr}, \mathrm{V}$ and $\mathrm{Pb}$. Unit-cell parameter changes on substitution and the structural role of " $\mathrm{C}^{2+}$ ". Neues Jarhbuch für Mineralogie Abhandlungen, 167(1), 89-123.

Morawska, A. (1997). The Lubliniec fracture zone: boundary of the Upper Silesian and Małopolska massifs, southern Poland. Annales Societatis Geologorum Poloniae, 67, 429-437.

Nieć, M., \& Bąk, B. (1993). Zinc-lead ore deposit in Lower Triassic (Roethian) dolomites at Bolesław (Olkusz region, Poland). Geological Quarterly, 37, 157-174.

Piestrzyński, A. (1992). Wybrane materiały do ćwiczeń z petrografii rud. Skrypty Uczelniane 1306, Wydawnictwa AGH, 393.

Przeniosło, S. (1971). Uwagi o genezie dolomitów kruszconośnych i okruszcowanie cynkowo-ołowiowe w świetle badań petrograficzno-geochemicznych w rejonie zawierciańskim. Kwartalnik Geologiczny, 15, 4.

Przeniosło, S. (1974). Cynk i ołów w utworach węglanowych triasu rejonu zawierciańskiego. Biuletyn Instytutu Geologicznego, 278, 115-201.

Sass-Gustkiewicz, M. (1996). Internal sediments as a key to understanding the hydrothermal karst origin of the Upper Silesian Zn-Pb ore deposits. In D.F. Sangster (Ed.) Carbonate-Hosted Lead-Zinc Deposits, SEG Special Publication, 4, (pp. 171-181). Michigan, USA: Society of Economic Geologists.

Sass-Gustkiewicz, M. (1997). Revised and completed paragenetic order of minerals in the Pomorzany lead-zinc deposit, Upper Silesian region, Poland. Mineralogia Polonica, 28, 46-80.

Sass-Gustkiewicz, M. (2001). The Upper Silesian Zn-Pb sulfide ore deposits (Poland) and ore forming processes. Geological Excursion guide, The Joint $6^{\text {th }}$ Biennial SGA-SEG Meeting, August 26-29, 2001 (pp. 64-76). Kraków, Poland: Wydawnictwo Naukowe „Akapit”.

Sass-Gutkiewicz, M., \& Dżułyński, S. (1998). Comments on the origin of strata-bound Zn-Pb ores in the Upper Silesia, Poland. Annales Societatis Geologorum Poloniae, 68, 267-278.

Sass-Gustkiewicz, M., Mochnacka, K., \& Socha, J. (2000). Formy występowania barytu w górnośląskich złożach rud cynku i ołowiu na przykładzie złoża Pomorzany. Prace Specjalne PTMin, 16, 131-147.

Senkowiczowa, H., \& Szyperko-Śliwczyńska, A. (1961). Zagadnienia stratygraficzno-facjalne. In Atlas geologiczny Polski (p. 8). Warszawa: Instytut Geologiczny.

Siedlecki, S. (1952). Utwory geologiczne obszaru pomiędzy Chrzanowem a Kwaczałą. Biuletyn Instytutu Geologicznego, 60, 230.

Smolarska, I. (1968). Charakterystyka złoża rud cynku i ołowiu kopalni Trzebionka. Prace Geologiczne Komisji Nauk Geologicznych PAN Oddz. w Krakowie, 47, 60.

Smolarska, I. (1974). Studia nad okruszcowaniem triasu w Polsce. Prace Mineralogiczne Komisji Nauk Mineralogicznych PAN Oddz. w Krakowie, 37, 71.

Strzelska-Smakowska, B. (1993). Możliwość występowania złóż rud Zn-Pb w obszarze Lubliniec-Koziegłowy. Geologia, Kwartalnik AGH, 19(3), 113-164.

Śliwiński, S. (1961). Warstwy olkuskie. Rudy i Metale Nieżelazne, 12, 526-529. 
Wielgomas, L. (1959). Dokumentacja geologiczna złoża rud Zn-Pb w rejonie Bibiela-Kalety. Centralne Archiwum Geologiczne PIG.

Wielgomas, L. (1961). Wyniki wierceń poszukiwawczych za rudami Zn i Pb w rejonie Koziegłów. Centralne Archiwum Geologiczne PIG.

Wielgomas, L. (1975). Poszukiwania rud Zn i Pb w rejonie Lubliniec-Niegowa. Centralne Archiwum Geologiczne PIG.

Wielgomas, L. (1979). Projekt badań geologiczno-poszukiwawczych rud Zn i Pb w N części regionu śląskokrakowskiego, obszaru Boronów-Niegowa. Centralne Archiwum Geologiczne PIG.

Wielgomas, L. (1980). Badania geologiczno-poszukiwawcze złóż rud $\mathrm{Zn}$ i Pb w N części regionu śląskokrakowskiego, na obszarze Koszęcin-Włodowice. Centralne Archiwum Geologiczne PIG.

Wyczółkowski, J. (1978). Osady triasu dolnego i środkowego. In J. Pawłowska (Ed.), Poszukiwanie rud cynku i ołowiu na obszarze śląsko-krakowskim. Prace Państwowego Instytutu Geologicznego, 83, 79-104.

Ziętek-Kruszewska, A. (1978). Charakterystyka mineralogiczna siarczków w utworach triasowych. In J. Pawłowska (Ed.), Poszukiwanie rud cynku i ołowiu na obszarze śląsko-krakowskim. Prace Państwowego Instytutu Geologicznego, 83, 211-215. 
